\title{
MISSIONARIES AND MURDER IN THE STRUGGLE FOR ZIMBABWE
}

\author{
Roger Southall \\ Department of Sociology, \\ University of the Witwatersrand, Johannesburg, \\ and Department of Political Studies, \\ University of Cape Town
}

Griffiths, S (2017), The Axe and the Tree: How bloody persecution sowed the seeds of new life in Zimbabwe. Oxford UK and Grand Rapids, Michigan: Monarch Books, 288 pp. ISBN 978085721789 9; e-ISBN 9780857215

The literature on missions and missionaries in colonial Zimbabwe is uneven, interlaced as it is with the broader question of church and state. There are studies of the arrival and development of missions, these linked to the role of individual denominations, and how they interacted with settler governments (for example, Madhiba 2010; Simmons 2000; Welch 2008; Zvogbo 1988); there is analytical treatment of the impact of missions upon African communities, notably how this clashed with local cultures and shaped new identities (for example, Kapenzi 1979; Mhike 2013) and there are studies of how missions and their denominations were indigenised (Mwandayi 2013). Additionally, there has been considerable interest in the role of the missions in providing education (for example, Zvogbo 1980), with much of this linked to the role of Garfield and Grace Todd: their pioneering work in promoting African schooling at their mission at Dadaya, Grace's work in creating what became a national curriculum for African schools and promoting teacher training, and the significant expansion of African education driven by Garfield during his feted (and fated) tenure as Prime Minister in the 1950s (for example, Weiss 1999). In turn, the interest in Todd leads on to attempts to wrestle with the intertwining of Christianity with colonial liberalism how it both inspired missionaries, or those they had trained, to challenge successive white minority governments, but rendered many cautious about political involvements in colonial society (Peaden 1979; Moyo 2015). Above all, however, there has been very substantial interest in how missionaries, the churches to which they adhere and African Chris- 
tians acted during the liberation war against lan Smith's government and how many missions were caught in the crossfire (for example Bourdillon and Gundani 1988; Lapsley 1988; Bhebe 1988). This was an unenviable situation, and missions responded variously. Although disposed against violence, many were unable (or unwilling) to unambiguously declare against the war (for fear of losing their African congregations) and some provided covert assistance to guerrillas. In quite a few instances, missionaries felt they had little option but to close their missions in areas where staff and congregants were seriously endangered.

The last theme remains highly contentious, not least regarding the brutal murder of nine Pentecostal missionaries and their four children at the Elim Mission, high up in the Vumba mountains, by nationalist guerrillas in June 1978. This was seized upon by the Smith regime to provoke sympathy for the settlers' cause. It continues to do so in rightwing circles to this day. Yet the story is much more complicated than the trope of 'terrorist atrocity' allows.

For this reason, a warm welcome should be extended to The Axe and the Tree. Authored by the son of the patriarch of the Elim mission (who happened to be back in Britain with his father and family at the time), it is not only an eloquent testament of remembrance to those who died, but one of the first 'insider' studies of the challenges faced by missions during the war, and how they responded to them. While the tale is deeply disturbing, it is simultaneously inspiring in that it seeks to overcome moral condemnation of the killers not only with understanding of their motivations, but by offering a message of reconciliation which all those concerned with a remaking of Zimbabwe will be eager to endorse, even if they do not share the author's Pentecostal faith in Christian redemption.

One of the book's endorsements refers to the text, correctly, as "by turns memoir, biography, crime investigation and political history". Engagingly written, it is not an academic text. Perhaps for that reason (!), it may acquire an admiring readership, especially amongst faith communities keen to pay tribute to latter day Christian martyrdom. Nonetheless, the book deserves academic attention. Based on interviews, primary documentation and a decent reading of the contemporary academic literature on Zimbabwe, it combines historical rigour with sensitive portrayal of the moral and political ambiguities with which ordinary people had to grapple if they were to survive a hideous war. Simultaneously, it poses questions about political and moral accountability, and more obliquely (if unintentionally) about the role of missionaries — and why 
their deaths, however brutal and undeserved, receive more attention than the slaughter of other innocents. It also tells us quite a lot about 'white Rhodesia' even though this book is very definitely not a contribution to the nostalgic Rhodesiana which can be found in too many bookshops.

The thrust of the story is easily told. Peter Griffiths (the author's father) went out to Rhodesia in 1960 to serve as missionary for the Elim Pentecostal Church, which had emerged out of revivalist currents in Wales in the mid-19 $19^{\text {th }}$ century. Only in his early 20 s, he was to serve under the wing of $\mathrm{Dr}$ Cecil Brien, who as a medical missionary had established an Elim mission in the remote Ruwange Valley in the country's north-east. Within a short time, Peter was courting Brenda, another British missionary, who he married in December 1963. By 1967, following the retirement of Brien, Griffiths became principal of the tiny, new Emmanuel Secondary School. Children soon followed, in the form of the author and his brother, and their early childhood, amongst African children of their own age, was clearly idyllic. Yet as the mission network of primary schools, secondary school and medical facilities expanded alongside the committed preaching of the gospel, Rhodesia was plunging into the abyss.

Nationalist movements had been banned by a government hellbent on retaining white minority rule, its determination stiffened by the Congo crisis of 1960. Contemptuous of Harold Macmillan's warnings about 'winds of change', white arrogance culminated in Smith's unilateral declaration of independence in 1965.

All went pretty well for the Smith regime until Mozambique gained its independence in June 1975. This was to expose Rhodesian troops to a front along the long expanse of the Mozambican border. Banned at home, the nationalist movements had committed themselves to armed struggle. With the arrival in power of Frelimo, the Zimbabwe African National Liberation Army (ZANLA), (the armed wing of Robert Mugabe's Zimbabwe African National Union (ZANU)), moved its bases from Zambia and Tanzania to a newly welcoming Mozambique.

We now know this was the beginning of the end for white Rhodesia. By the late 1970s, Stephen Griffiths tells us ( $p$ 117), the Rhodesian military could deploy only about 1500 combat troops on any one day, but they were innovative, well trained, highly armed and well supported with extensive artillery support and air cover. In contrast, ZANLA had much larger numbers, but minimal artillery and no air support, and hence found it difficult to sustain a prolonged firefight. Yet they quickly learnt that the landmine was a potent instrument of war, capable 
of disrupting Rhodesian troop movements across vast areas, while undermining white civilian morale. Steadily but surely, the Rhodesian army began to lose control over rural areas, white farmers were increasingly exposed to danger, and white civilians largely confined to urban areas. The attempt by Smith in 1978 to stave off mounting international pressure by forging an Internal Settlement, whereby he handed over the premiership to Bishop Abel Muzorewa, was doomed to early failure as white morale collapsed and nationalist confidence stiffened. Following tempestuous negotiations at Lancaster House, the temporary restoration of British colonial rule, and a resultant election, Mugabe's ZANU came to power at independence in 1980.

By the mid-1970s, the Elim missionaries found themselves living in the middle of a war zone. A first visit to the mission was paid by ZANLA guerrillas in April 1976. They wanted and were seemingly supplied with medicines, only to be gunned down by Rhodesian troops a short time afterwards. As such incidents multiplied, government services and other mission hospitals along the north-eastern border were closed, leaving Elim increasingly exposed. Soon the mission hospital staff found themselves treating both civilians and soldiers horrifically wounded by land mines, as battles between Rhodesian troops and ZANLA guerrillas raged in the bush around them. African mission staff and civilians were often caught up in the cross fire, killed and wounded, and subjected to massive intimidation from both sides.

Fear crept closer following the murder of three Roman Catholic missionaries in Lupane in December 1976. Although the Elim missionaries bravely held their ground, ultimately the decision was taken to move the secondary school to the premises of Eagle School, on the edge of Umtali, and abandoned two years previously under the pressures of war. With the rationale that the presence of white missionaries put them in increased danger, medical and mission work at the Elim mission was now handed over to Zimbabwean staff, and the white missionaries transferred to Eagle. It was here, amidst difficult conditions (as students seemed increasingly affected by nationalist sentiment), that the murder of the missionaries was to take place on the evening of 23 June 1978. Griffiths' accounts of the murders, pieced together from police reports and later guerrilla confessions, is heart-rending. Inevitably, the school had to be closed, and the students transferred to other schools.

The last third of the book is devoted to the aftermath. How Peter Griffiths called, to the outrage of white Rhodesians, for forgiveness to the killers; how he was soon to be recruited into devising curricular for 
religious education for the Ministry of Education; how the work of the mission was to be continued during years ahead by its local staff. The book closes with a chapter whereby the author explains not only his need to know more precisely why and how the missionaries died, but to challenge those who had argued that the missionaries had been naïve, ignorant, and politically involved and who implied that they were such damn fools that they almost deserved to be killed ( $p$ 325). Equally, Griffiths wanted to explore what was for him the deeper meaning. "How could God purpose the events of that night? Was God a monster?". Yet what if there was "a divine reason underlying it all?". The answer he finds is that "God actively weaves the evil deeds that men do into His Sovereign rule over all things, while at the same time never condoning or accepting evil, never depriving men and women of either their freedom or their responsibility for what they do" ( $p$ 331). In the wake of the massacre, he takes strength in the fact that the missionaries had shared the sufferings of the people of Zimbabwe, and that they had prepared the way for forgiveness. He relates how individual guerrillas responsible subsequently "came to faith", one in particular becoming a family friend.

Whatever readers' take on Griffiths' Pentecostal beliefs and musings, it is impossible not to profess an admiration for the white missionaries of the Elim mission, along with sadness about the brutal way in which these still mostly young lives were brought to such a tragic end. Even so, even while acknowledging that one is writing from the safety of one's armchair, one is brought to some troubling thoughts and reflections.

The first of these is how the Elim mission murders were eagerly seized upon by the regime for propaganda purposes. At a moment when Smith was seeking to legitimise the internal settlement, the killings were used to construct a political narrative which, allowing for no other interpretation, depicted the liberation struggle as inherently barbarous and illegitimate. It was used not only to stoke white fears, but to whip up a frenzy of retribution and righteous defence of white Christendom against communistic and godless terrorism. The Anglican Bishop of Mashonaland called upon Britain to send in troops "to deal with" the terrorists, while the Tory party at Westminster bayed for blood. Dale McKinley (also, incidentally, the son of missionaries) recalls how special remembrances services for the 'massacre' were held at his high school, while in subsequent days, the pupils were taken out of classes to cheer as Rhodesian Air Force planes, returning from their latest murderous raids into Mozambique, performed triumphalist barrel rolls overhead 
(private communication with Dale McKinley).

It is clear this was a mis-use of the killings and ran against what the Elim missionaries stood for. Even so, it leads on to the reader's discomfort about the differential attention accorded to black and white body counts. This is no criticism of Griffiths, who has legitimate personal reasons for writing his reconciliatory account. Yet we read, for instance, about Rhodesian cross-border raids into neighbouring countries, using guerrilla 'atrocities' as justification, killing hundreds of refugees. Griffiths recalls one of the most notorious such incidents, the raid on ZANLA's camp at Nyazonia, 35 kilometres inside Mozambique. This raid was conducted in August 1976, two years before the Elim killings. Selous Scouts, dressed in Mozambique army uniforms, calmly drove into the camp and directed a devastating barrage of fire at close range into a 5 000-strong crowd of men, women and children, who had gathered around them to welcome those they had taken as allies. "Within seconds, the parade ground was transformed into a charnel house, the celebratory atmosphere replaced with the thunderous chatter of the guns and the screams of the wounded and dying. Hundreds were killed, among them women and children" ( $p$ 284). As Griffiths relates, this massacre at Nyazonia was later cited by one of the guerrillas as one of the motivations for the killing of the Elim missionaries.

Does this justify the killings? Does any act of violence justify another? In civilian life obviously not, yet it leaves us pondering about the ethics of any so-called 'just war'. Whatever our answer, it forces us to think about how to write about atrocities in war, and how such writing may come to be employed for uses unintended by the writer. One fears, for instance, that the nuances of interpretation which characterise Griffiths' text may be overlooked by in some less reputable evangelical circles in the United States (US) to celebrate white Christendom. Even more uncomfortably: why should the deaths of the missionaries be so tenderly recorded while those of the countless Africans who died in the conflict are forgotten?

This leads on to a consideration of how 'white Rhodesia' unavoidably enters the text. Let us recall how missionaries were invariably regarded with deep suspicion by the rest of white society. Dwelling amongst 'natives' in the bush, speaking their languages, mixing amongst them freely, missionaries enjoyed relationships with their African host communities which were founded upon a mix of white paternalism, nonracialism, friendship and mutual respect. Even so, there remained a gulf between white and black dictated by the colonial relationship. Griffiths himself was sent away from the mission to boarding school follow- 
ing a telling incident. After attending a children's party in town, yet more comfortable with Shona friends, a white parent had remarked to his own parents that he and his brother were going to have difficulty relating to other white children as they grew up. This worried his parents, so soon the Griffiths boys were packed off to a boarding school in Salisbury. On the way there, riding in a truck driven by an African driver from the mission, they were stopped by a white soldier who demanded angrily why he and his brothers' parents had allowed them to travel with a truckload of 'kaffirs'. Griffiths recalls how this was just the beginning of his sense of being pulled apart between two worlds ( $p$ 81).

This describes the dilemmas faced by the missionaries. As the war intensified, they were pulled into a tangled moral maze. The law dictated that they were required to report any presence of guerrillas to the authorities. If they did not, they faced either long jail terms or deportation. However, if they did, they were likely to not only lose the trust of their host communities, but to invite brutal retribution. Griffiths relates how his parents and the missionary team at Elim sought to adopt a stance of neutrality which "was neither passive nor disengaged" ( $p$ 149). They embraced neither the nationalist cause nor the "Christian war against communism", yet moral quandaries were unavoidable. Deciding that his first duty was to save lives, Griffiths' father ensured that details of landmine placements found their way to the Rhodesian authorities, yet this in turn, incurred great risks for him, his family and the mission. These were the years, writes the author, of "secrets and silence, shadows and darkness, corrosive and pervasive fear ... years of blood and violence" ( $p$ 149). As time moved on, as the situation worsened, the mission was pulled inexorably into the maw of Rhodesian security, for all that the missionaries were regarded as 'kaffir-boeties'.

The moral quandaries did not stop there. Who was to take responsibility for atrocities? What action should be taken in response? We are all familiar with the phrase that truth is the first casualty of war. The Rhodesians were never apologetic, whatever the damage they wrought upon civilians. Fortunately for them, even though knowledge of their crimes filtered through to networks which supported the liberation struggle, it tended to be ignored or brushed aside by elites in the West, notably the United Kingdom (UK), who if they were not supporting the regime were keen to be rid of the awkward problem in distant Rhodesia. Unsurprisingly, while the British government of the day expressed its ritual outrage at the Elim killings, it allowed the hullabaloo to die down so as to be able to talk to both sides of the conflict to bring about a viable settlement. Even if this was less than honourable, it was 
at least some sort of arguable excuse.

Yet the liberation movements were just as mealy-mouthed. Supposedly they were on the side of the angels, yet when they were less than angelic they were not keen to own up. ZANLA denied responsibility for the Elim killings or shifted the blame on to indisciplined elements within their ranks, even though it emerged later that they had a military rationale. Garikai, one of the guerrillas who later confessed to the killings explained that ZANLA commanders wanted to clear the bush to make way for more crossing points northwards into Rhodesia through an area that was at the time still densely populated. Killing the missionaries and closing the school would frighten people and expand a range of crossing sites from Mozambique. This would also batter white morale (after all, the rape of white women by black men was regarded as the ultimate crime) and undermine the tottering government. The missionaries were an easy target for a major atrocity, which was deliberately gruesome and racially targeted ( $p$ 288). However, the confession of an individual perpetrator is not the same as the movement acknowledging its actions. Indeed, ZANU was to continue to deny its responsibility for the killings, rendering it dangerous for Garikai to remain within the independent Zimbabwe.

Can we accept such military rationales as justification? Or do we expect too much of oppressed peoples if we expect them to obey 'rules of war' in struggles for liberation - in an age when supposedly civilised Western governments dismiss civilian casualties in 'the war against terror' - in the Yemen, Iraq, Syria or wherever - as 'collateral damage'? It takes philosophers or theologians with clearly enunciated ethical or religious principles to come up with suitably argued answers and hopefully, processes of law to back them up. However, in a brutally unequal and unjust world, it may well be that the choice between black and white will all too often turn out to be shades of grey.

Ultimately, the Elim killings must be viewed against the tragedy that independent Zimbabwe was to become. In turn, that was shaped by the rigidity and racism of colonial settler society. While this book raises many issues - political, philosophical, historical — we may hope with its author that the lives and deaths of the Elim missionaries did indeed sow the seeds of a better future for Zimbabwe.

\section{Bibliography}

Bourdillon, M and P Gundani (1988), "Rural Christians and Zimbabwe's Liberation War", in Hallencreutz, C and A Moyo (eds), Church and State in Zimbabwe. 
Harare: Mambo Press, pp 147-161.

Kapenzi, G (1979), The Clash of Cultures: Christian Missions and the Shona of Rhodesia. Lanham: University Press of America.

Lapsley, M (1988), "Anglican Church and State from UDI in 1965 until the Independence of Zimbabwe in 1980", in Hallencreut, C and A Moyo (eds), Church and State in Zimbabwe. Harare: Mambo Press, pp 115-126.

Madhiba, S (2010), "Methodism and Public Life in Zimbabwe: An analysis of the Wesleyan Methodist Church in Zimbabwe's impact on politics from 18911980". PhD thesis. University of Pretoria.

Mhike, I (2012), "'Untidy tools of colonialism': Education, Christianity and social control in Southern Rhodesia: the case of 'night dances' - 1920s to the 1930s", Studia Historiae Ecclestiasticae, Vol 38, Supplement, pp 57-79.

Mwandayi, C (2013), "The Rise of African Christian Consciousness: Exploring the Trajectory in the Africanisation of the Catholic Church in Zimbabwe, 19341982", The Dyke, Vol 7, No 3, pp 61-77.

Moyo, F (2015), The Bible, the Bullet and the Ballot: Zimbabwe - The Impact of Christian Protest in Socio-Political Transformation. Eugene, Oregon: Wipf and Stock Publishers.

Peaden, W (1979), "Aspects of the Church and its Political Involvement in Southern Rhodesia, 1959-1972", Zambezia, Vol 7, No 2.

Simmons, D (2000), "Signs of the Times: Missionaries and Tribal Genesis in Southern Rhodesia", Transforming Anthropology, Vol 9, No 2, pp 3-18.

Weiss, R with J Parpart (1999), Sir Garfield Todd and the Making of Zimbabwe. London and New York: British Academic Press.

Welch, P (2008), Church and Settler in Colonial Zimbabwe: A Study of the History of the Anglican Diocese of Mashonaland, Southern Rhodesia 1890-1925. Leiden and Boston: Brill.

Zvogbo, R (1980), "Government and Missionary Policies on African Secondary Education with special reference to the Anglican and Methodist Churches 1934-1971. PhD thesis, University of Edinburgh.

Zvogbo, R (1988), "The African Franchise Question: An aspect of Church-State Relations in Colonial Zimbabwe, 1921-1972", in Hallencreut, C and A Moyo (eds), Church and State in Zimbabwe. Harare. Mambo Press, pp 29-50. 